\title{
The History of Fuel and Energy Complex Interests Lobbying in the Russian Federation in 1990-2000
}

\author{
Ruslan R. Vildanov \\ Department of International relations, history and Oriental \\ studies \\ Ufa State Petroleum Technological University \\ Ufa, Russia
}

Svetlana V. Shalagina

Department of International relations, history and Oriental studies

Ufa State Petroleum Technological University

Ufa, Russia

\author{
Artur R. Suleymanov \\ Department of International relations, history and Oriental \\ studies \\ Ufa State Petroleum Technological University \\ Ufa, Russia
}

Dinar N. Gabbasov

Student

Ufa State Petroleum Technological University

Ufa, Russia

Elnur T. Mekhdiev

Center for Post-Soviet Studies of the Institute of international studies Moscow State Institute of International Relations (University) of the Ministry of Foreign Affairs of the Russian Federation Moscow, Russia

\begin{abstract}
The article describes the problem of lobbying in the most important sphere of the Russian economy - the oil industry. Features of the emergence of oil companies and lobby groups in Russia are examined in the article. The largest sectoral associations lobbying the interests of oil-industry companies are also noted, a conclusion is drawn that the main trends in lobbying activity in 2000-2010 are changing.
\end{abstract}

Keywords-Lobbying; Fuel and energy complex; Gazprom; Rosneft; Lukoil

\section{INTRODUCTION}

Initially, the word "lobbyists" meant visitors who applied to various state institutions. In the 19th century, politicians believed that it was impossible to tolerate ordinary citizens in conference rooms where laws were enacted. Therefore, various kinds of petitioners were waiting in the halls and reception rooms, otherwise called the Lobby. Hence the name of this term. Lobbying in Russia has become a subject for discussion since the problem was stated in 1994. It is then that the first law on lobbying started to be prepared in Russia. But the topic of lobbying is still relevant in Russia. In a figurative expression of the researcher Lepekhin, lobbying in Russia is like an iceberg, it has become a part of political reality and is natural for it [5]. The visible "tip of the iceberg" is mainly expert-advisory structures, which include representatives of interested groups, for example the Public Chamber of the
Russian Federation, the councils under the President of the Russian Federation. But most remain "under water". According to the authors, Russian lobbyism existed and keeps on existing in the form of informal relations of promoting interests.

It has to be noted that petroleum production plays the most important role in the economy of the modern Russian Federation. The state actively interferes in the work of petroleum industry, regulates the allocation of quotas and duties. Therefore it is no wonder that this industry is a rallying point of lobbying efforts of all the parties concerned. Here, the economic interests of various oil and gas companies, both Russian and foreign, and the state, related to gaining petroleum revenues, clash.

The authors of this work took into consideration the fact that many important aspects of lobbying in Russia are still poorly studied, both in Russia and abroad, and tried to fully consider this fact while performing complex scientific research, analyzing mechanisms and technologies of lobbying interests in a political process.

The objective of the present study is to define the features of petroleum lobbying as sectoral lobbying in Russian Federation at present stage, specificity of its emergence and interests promotion. Also it is necessary to review the changes in the methods of lobbying in the petroleum industry since the moment of its emergence. 


\section{MATERIALS AND METHODS}

It should be understood that the decisions of the authorities rarely suit everyone. There are always a lot of different interests and opinions in a society. Each interest group wants its own interests to be taken into account, wants to be heard. That is why the subjects concerned, specifically the lobbying subjects, are trying by all acceptable (and maybe not quite) means to make it so that the state would pay attention to them. Even better if state structures would take their interests into account and support them as far as possible.

The authors used the following methods and techniques: system analysis; comparative evaluation, based on the categories of identity and distinction, with the goal of revealing identical or distinct characteristics of political institutes and processes; "stages of cases consideration" as an instrument that makes it possible to discover the trends and get necessary generalization; historical analysis: synchronic analysis, which presupposes studying the phenomenon in the context of historical circumstances; chronological, aimed at successive consideration of historical events; diachronic, focused on periodization and historical parallels, historical modeling in respect to political processes, technologies, institutions. Furthermore, the following were used in the research: system-functional measurement; content-analysis of documents; descriptive and correlative characteristics; political and prognostic tools. The empirical base of the research is constituted by Federal laws of the Russian Federation; materials from open sources on the Internet; massmedia publications.

\section{DISCUSSION}

Under the current state arrangement of modern Russian Federation, there are four basic areas for lobbying: the President's Administration, the Government, the Federal Assembly (the State Duma and the Federation Council), and to a lesser degree regional and local authorities. The process of lobbying is managed in order to get some legislative act, instruction or a decree passed or not passed.

In the process of research, a circle of individuals comes forward as lobbying subjects, which may include individuals, as well as associations, unions, organizations etc. The Russian government, taking into consideration the capabilities of different lobbying subjects and being represented by competent authorities, comes to certain decisions. That is why those who make a decision are being influenced. That is what we call "lobbying". In reality lobbying is advocating one's interests at the political level, embodied in the promotion of beneficial bill drafts, support of those who can help achieving this goal.

In the modern world, industry lobbyism is quite a normal and necessary process, exactly the same as political lobbyism. In general, appropriate committees were formed in the Parliaments of different countries in order to be more competent to understand the issues of various industries, banking, science, culture, public associations and religious organizations. The Duma committees were created precisely to conduct bills through the Duma in the interests of certain industries. Similarly, the executive branch has been built along the line of industry.

Thus, sectoral lobbyism is a process to promote the interests of a particular industry in government bodies. The main goal here is to achieve certain preferences for this industry. The main task that industry lobbyists are facing is to reduce taxes on business (for example, the tax on mining), tax incentives for the development of new deposits. Also, little attention is paid to legislative changes, attempts to increase budgetary subsidies. In principle, the main goal of sectoral lobbying, something that all measures should lead to, is to increase the capitalization of this industry and the profitability of companies.

\section{RESULTS}

Surprisingly, even in the Soviet Union there was lobbyism. In the Soviet period there were methods of promoting economic interests, especially in large industrial enterprises, although of course no one called this lobbying them. Even in the lexicon such a term will appear only in the 1990s.

Nevertheless, there was a powerful and strong regional and functional lobby in the USSR. It is another matter that lobbying was carried out at that time on the basis of horizontal differentiation, i.e. organized according to the territorialsectoral principle. The main channels for lobbying were ministries and departments, the State Planning Committee and Gossnab, as well as committees of the CPSU. They promoted the interests of various industry groups.

The situation did not change much by the 1980s, and only after the Perestroika did the real economic sector of the USSR begin to separate more and more from the ideology. The already established and by that time mighty territorial and industry clans strengthened their positions and became increasingly independent of the center. For complete independence, they lacked only the legal securing of property, which actually belonged to them. This consolidation was one of the results of the Perestroika. Enterprises after the adoption of the Law "On the State Enterprise" in 1987, and the Law "On Cooperation" in 1988 began to get rid of the tedious trusteeship of higher ministries and departments. In fact, this was the beginning of the collapse of the old Soviet system of lobbyism and the emergence of a new one.

This was clearly manifested in the fact that large enterprises had the opportunity to resolve issues directly, albeit with the help of lobbyists, immediately with the Gosplan or even the Council of Ministers of the USSR. The result of the 19th Party Conference in 1988 was the fact that state-owned concerns were created on the initiative of the government. The most famous of them is Gazprom, established on the basis of the Ministry of the gas industry of the USSR, headed by the last Minister of the gas industry of the USSR, VS. Chernomyrdinym.

Nevertheless, at the first stage it seemed that nothing had changed. The strongest groups of lobbyists remained the same as in the Soviet period. These were monopolies, and mainly focused on the export of oil and gas, minerals. These industries had and have lobbyists in the ministries, 
government, administrations of all levels, ensuring the advancement of their interests. In addition, the main channels of lobbying from the USSR have not disappeared - branch ministries with their colleges.

1993 may be considered a border point when oil and gas lobby got finally formed in Russia. It might be represented as the union of the main groups of the energy and fuel complex. Altogether it may be noted that the mechanism of lobbying has not changed much. It is still those same regional and industry clans that are in power [5]. This is explained by the fact that since 1992 the New Russia's political system began to be formed, as well as a new economic system. One of the important processes which took place in Russian economy was the process of privatization, which meant the transition of state property into private hands. In fact, what happened while creating new legal basis is that property was secured by big functionaries of the specialized structures of the former USSR [6], by the so-called "red directors". Petroleum industry of the Russian Federation provides us with many vivid examples. For example, V. Alekperov used to be the first deputy minister of the oil and gas industry of the USSR, after which he became the president of Lukoil petroleum company; in his turn, S. Muravlenko became the head of the Yuganskneftegaz; V. Bogdanov managed Surgutneftegaz since the Soviet times, since the mid-1980s [7]. Under the new economic and political circumstances, the reorganization of the petroleum industry had not only an economical, but also a political meaning. Under the circumstances of crisis and impoverishment of the population, the petroleum industry was a relatively stable and monetary sector of economy. Against the background of financial independence and self-sufficiency, the oil industry started to self-organize in political terms very quickly as well. Each company gradually developed its own corporate policy, its own lobbying groups to enforce the authorities.

The Union of Oil Producers became the most known organization of the kind, and after it was joined by Gazprom, it became the Union of Oil and Gas Producers. Along with them, the Interregional Association of the Economic Cooperation of the main oil and gas regions and the Russian Union of Petroleum Exporters emerged and started actively manifesting themselves in public life [4].

The history of the Union of Oil Producers of Russia began in February of 1992. The Union was created on the initiative of leaders of the largest Russian petroleum refining companies with the purpose of defending the interests of the industry [3].

One of the goals of the Union was to engage experts to the expertise of government's decisions so that the interests of the oil industry would be considered more fully. Also the Union's representatives wanted to participate in the development and implementation of state programs related to fuel and energy complex. The imperfection of Russian legislation certainly demanded that oil companies would work actively, pushing their interests through all branches of power. In the process of lobbying its own interests, the Union of Oil and Gas Producers interacted actively with the Russian government, local legislative assemblies, and especially with theRussian parliament [1]. In this regard, the Union of Oil and Gas
Producers quite effectively cooperated with specialized Committees of the State Duma of the Russian Federation. The main task in this aspect was to amend the Tax Code in order to cut down the oil industry taxes.

It may be stated that the Union of Oil and Gas Producers of Russia is the largest lobbying organization in Russia that promotes the interests of the oil and gas complex.

Another large lobbying organization - the Interregional Association of the Economic Cooperation - originated July 17 , 1994. It originated on the basis of interaction of the main oil and gas regions, such as: the Republics of Bashkortostan, Komi, Tatarstan, Orenburg, Sakhalin, Tomsk, Tyumen regions, Khanty-Mansiysk and Yamalo-Nenets districts. The Association should have been unifying the efforts of the regions on the development of oil and gas industry. It worked actively together with the Ministry of Fuel and Energy on the development of legislation concerning the exploitation of oil and gas deposits.

\section{CONCLUSION}

It may be noted that in the 1990 s, despite all the efforts, an integrated lobbying policy promoting the interests of the oil and gas industry was not created. Lobbying organizations failed to become mighty structures, analogous to OPEC, through which oil companies would generate common decisions. It should be taken into consideration that the characteristic of Russian lobbying in fuel and energy complex is that the significant part of petroleum lobby is aimed at protecting their own corporate interests. In the 2000s petroleum industry of Russia suffered radical changes. The situation with the Yukos petroleum company became the most memorable event. In 2003 the Yukos case emerged, followed by the sale of the company. The result was that the state company Rosneft became one of the leaders of Russian petroleum market. In the same period Gazprom bought out the controlling interest of the OAO Sibneft, which became Gazpromneft. The purchase of TNK by Rosneft in 2013 may be considered the final chord. We may notice that the owners of main petroleum companies changed. Today only three companies have a key influence in the petroleum industry. At the top of that, their level is absolutely inaccessible to smaller rivals [2]. Out of the three Gazprom and Rosneft are state corporations and only Lukoil remains a private company, a relic of privatization of 1990s.

So, the trend in Russian petroleum industry in the 2000s was a redistribution of property, which may in short be characterized as deprivatization. From the point of view of the state officials, or as they called themselves, "statesmen", it was a correct answer to the 'incorrect' privatization of 1990s, in particular to the "Loans for shares auctions", which created largest financial-industrial groups of a type similar to Yukos.

Essentially, the process of gaining state control over national natural recourses is not something unique to Russia. Other oil-producing countries also went through a similar process of "gathering" oil equities, for example, Brazil, Venezuela, Malaysia, Saudi Arabia, and Iran. In Russia, these changes took place together with the process of strengthening of the state power hierarchy. Also it should be noted that 
Russian authorities had serious apprehension concerning the sale of oil companies to foreigners.

As it may be seen, in the 2000s the owners of the main oil companies changed. Today there are only three strong companies, lobbying their interests in the petroleum industry. The main channels of lobbying activity also changed. In a new situation oil companies switched to executive power bodies. The government of the Russian Federation unconditionally remains the main object of lobbying activities. Contacts with President's Administration should be noted separately, which perhaps has the biggest value in strategic decisions.

To sum up, it can be stated that oil companies in modern Russia can influence and in fact influence the decision-making by state structures. To implement this influence, companies must have substantial financial and administrative resources to influence the decision-making process. It can also be noted that the interests of companies and the state do not always contradict each other (for example, regarding taxes). Despite significant differences, the interests of the state and business can coincide, be of a general nature.

This is confirmed by the example of Russia's largest association of oil companies, the Union of Oil and Gas Producers. The Council of this Union actively and constructively participated in the development of the Energy Strategy of Russia until 2030, helped the state in the formation of the oil strategy.

In principle, the state should discuss, and even coordinate with entrepreneurs its actions of a strategic nature. In the same way as to conduct a balanced credit and tax policy. So that entrepreneurs did not list in contracts the decisions of the Government of the Russian Federation as an example of acts of force majeure.

An important factor in the development of relations between oil companies and the state could be an open explanation of the Government's position and future steps. Businessmen should clearly understand why the authorities are adopting or not adopting certain laws, whether these actions will go to benefit or to the detriment of their activities. Companies need to see a global perspective, plan their activities not for the next two or three years, but for 10-15 years ahead. To do this, the business must have an idea of the state's plans for this period of time. This is also necessary for exploration of new deposits, investing money in the development of deposits, capital structures.

In modern Russia, lobbyism often has a hidden, shadowy nature due to the lack of legal rules and procedures. This leads to the establishment of complex mechanisms and forms of defending their interests, primarily on the part of big business. The mechanism of interaction between Russian lobby groups of entrepreneurs, public associations and organizations, citizens, as well as foreign firms, is now quite hidden and nonpublic. In such conditions, the most advantageous in interaction with government bodies are the more organized pressure groups representing the interests of large companies with the largest monetary or administrative resources, certain links on the federal and regional leadership.
Thus, lobbying in the oil and gas complex today requires ordering and creating "the rules of the game." It was this kind of activity that the oil lobby was engaged in that developed the strategy of relations with the authorities. It was these groups of influence that were engaged in forming a systemically organized set of public, legal norms in the field of the oil business, in improving the legal field, although sometimes in their own interests. Over the past decades, the situation in the oil and gas sector has improved significantly. Russian natural resources will remain necessary throughout the rest of the world, despite an active declaration of a policy of using alternative energy sources. Therefore, Russia's energy resources will remain in demand in the foreseeable future, which requires the continuation of an organized state policy in this sphere, and it is necessary to unite efforts of both business and state synergistically.

\section{REFERENCES}

[1] R. Vildanov, "Lobbying and the distribution of influence on the topics of fuel and energy complex in the State Duma of the 1st convocation (1993-1995)," Oil and Gas Business, 2012, vol. 10, 2, pp. 110-115. (In Russian)

[2] P. Ivanov, "Features of the functioning of interest groups in the State Duma of the Federal Assembly of the Russian Federation," PhD Thesis, 2014, Moscow: Moscow State University. (In Russian)

[3] Zh. Kurgaeva, T. Khalilova, "Cooperation of authorities and business in the field of solving social-economical problems (the case of hydrocarbon processing enterprises)," Bulletin of Kazan Technological University, 2011, 12, pp. 205-2011. (In Russian)

[4] Zh. Kurgaeva, T. Khalilova, "Industrial and corporate lobbying in activities of hydrocarbon production and processing enterprises,' Bulletin of Kazan Technological University, 2013, 14, pp. 274-277. (In Russian)

[5] V. A. Lepekhin, "Lobbying in Russia and the problems of its legal regulation,"Transformation of Russian regional elites in a comparative perspective: a collection, Moscow scientific societies fund, Scientific reports, 1999, vol. 76, pp. 57-85. (In Russian)

[6] P. Seleznev, A. Shaposhnikov, "Lobbying in the oil and gas sector of modern Russia," Vlast', 2017, 5, pp. 122-129. (In Russian)

[7] K. Simonov, Russian oil: the last repartition. Moscow: Eksmo, 2005. (In Russian) 